\title{
Analisa Performa RStudio Server Berbasis Cloud Menggunakan Elastic Stack sebagai Sistem Manajemen Metrik
}

\author{
Krisna Aditama Ashari ${ }^{\# 1}$, Is Mardianto ${ }^{\# 2}$, Dedy Sugiarto ${ }^{\# 3}$ \\ \#Program Studi Teknik Informatika, Fakultas Teknologi Industri, Universitas Trisakti \\ Jalan Kyai Tapa No 1 Grogol, Jakarta Barat, DKI Jakarta 11440 \\ ${ }^{1}$ krisna0640019040030std.trisakti.ac.id \\ 2mardianto@trisakti.ac.id \\ ${ }^{3}$ dedy.sugiarto@trisakti.ac.id
}

\begin{abstract}
Abstrak-Reliabilitas atau keandalan merupakan salah satu sifat penting pada sebuah server dalam melayani pengguna. Salah satu cara mengukurnya ialah dengan melakukan uji perfoma. Penelitian ini bertujuan untuk mengetahui kemampuan RStudio Server pada infrastruktur cloud saat digunakan oleh multiuser dengan Elastic Stack sebagai sistem yang menangani pengumpulan, penyimpanan dan visualisasi data metriknya. Tahapan dimulai dengan mengumpulkan data berupa metrik sistem oleh Metricbeat, lalu diproses Logstash dan disimpan menjadi index dalam Elasticsearch, visualisasi data ditampilkan oleh Kibana. Pengujian kinerja server dilakukan dengan menjalankan script $R$ berdurasi 2 menit dan 7 menit secara simultan. Hasil pengujian berupa catatan CPU Usage, Memory Usage dan durasi penyelesaian script selanjutnya di plotting pada $R$. Hasil analisa dari plotting data menunjukkan jumlah user yang dapat menggunakan Rstudio Server dengan spesifikasi 2 CPU dan RAM 4GB secara optimal ialah maksimal 2 user pada script dengan run time 2 menit dan 7 menit, lebih dari jumlah user itu akan mempengaruhi waktu proses penyelesaian script menjadi tingkat performa sedang hingga berat.
\end{abstract}

Kata kunci- Rstudio Server, Cloud, Elastic Stack, Metrik, Plotting

\section{PENDAhuluan}

Server adalah komputer yang menyediakan berbagai jenis layanan kepada komputer lain dalam jaringan komputer [1]. Seiring pesatnya perkembangan teknologi, layanan server kini mampu diakses lebih luas dan fleksibel melalui internet berbasis cloud computing. Cloud computing atau komputasi awan adalah metode dimana kemampuan teknis teknologi disediakan sebagai layanan (as a service) sehingga pengguna dapat menggunakannya melalui internet tanpa mengetahui infrastruktur apa yang ada di dalamnya [2]. Salah satu contoh penerapannya pada saat ini ialah mendukung pembelajaran dan pelatihan via online mengenai data analisis menggunakan RStudio Server. RStudio Server adalah server integrated development environment (IDE) berbasis web untuk bahasa
$\mathrm{R}$, yang memungkinkan untuk tiap penggunanya mengakses environment sendiri kapanpun melalui antarmuka web [3]. Dengan RStudio Server berbasis server cloud memberikan banyak kemudahan di sisi pengguna, dimana kebutuhan spesifikasi hardware seperti CPU, RAM dan lainnya telah diakomodir oleh server yang menaungi. Karena peran server cloud yang sentral inilah analisa performa server diperlukan dalam mengetahui berapa maksimum pengguna yang dapat dilayani secara optimal dari spesifikasi server yang dimiliki. Sehingga nantinya dapat menyesuaikan alokasi infrastruktur cloud yang digunakan dengan jumlah pengguna aplikasi yang dapat dilayani. Untuk itu dibutuhkan sebuah sistem yang mampu memonitoring performa server dalam memberikan layanan, terutama berkaitan dengan data metrik sistem. Seperti penelitian lain terkait yang menggunakan Network Monitoring System untuk memantau sumber daya virtual server [4] dan analisis performansi metrik pada Windows Azure VM dan AWS EC2 [5].

Sebagai sistem manajemen metriknya digunakan Elastic Stack. Elastic Stack adalah kumpulan perangkat lunak sumber terbuka yang berguna untuk mencari, menganalisis, dan memvisualisasikan log yang dihasilkan dari sumber apa pun dalam format apa pun [6]. Elastic Stack terdiri dari empat komponen yang berdiri sendiri, yaitu Logstash, Beats, Elasticsearch, dan Kibana [7]. Implementasi Elastic Stack di server adalah solusi yang tepat untuk manajemen log dan metrik karena dapat menampilkan informasi tentang tren, statistik, dan anomali kepada administrator [8] Beberapa penelitian sebelumnya mengenai penggunaan Elastic Stack antara lain, Implementasi Elastic Stack sebagai pemroses data IoT [9], penelitian memantau kinerja server web apache dalam menangani request user [10] penelitian lain juga menggunakan Elastic Stack sebagai sistem pengolah big data [11]. Plotting data sendiri bertujuan untuk memvisualisasikan variasi atau menunjukkan hubungan antar variabel [12]. 
Berdasarkan latar belakang diatas maka mengetahui penggunaan resources server dengan melakukan uji performa diperlukan untuk mempermudah dalam menentukan skema penggunaan aplikasi sehingga didapatkan hasil yang optimal.

\section{Metode Penelitian}

Metode yang digunakan pada penelitian ini terdiri atas beberapa tahapan sebagai berikut:

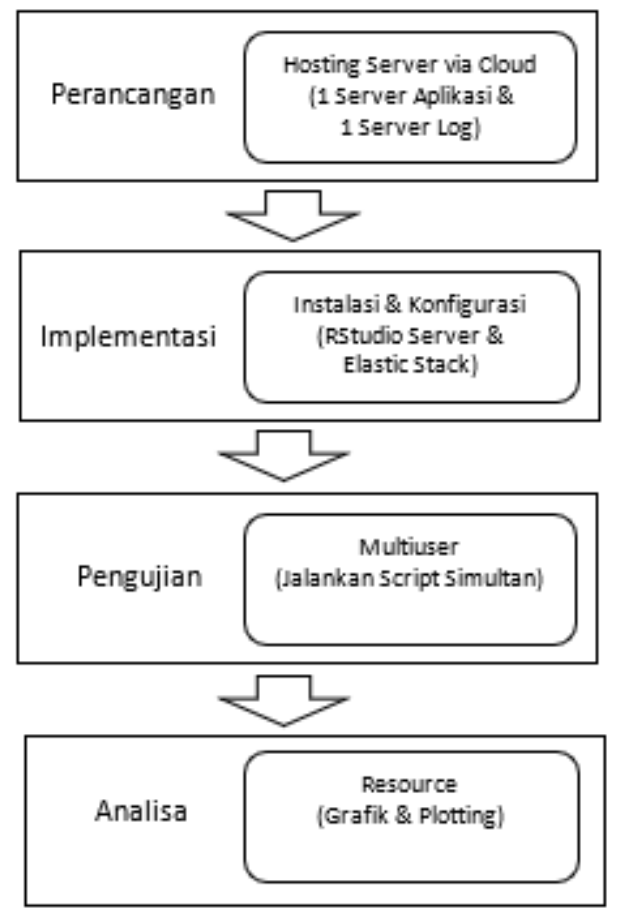

Gambar 1. Diagram alur

\section{A. Perancangan}

Dalam penelitian ini untuk infrastruktur menggunakan resources salah satu provider cloud computing, yaitu Digital Ocean. Diperlukan 2 server yang masing-masing difungsikan sebagai server manajemen metrik dan server aplikasi, seperti yang ditanpilkan Gambar 2

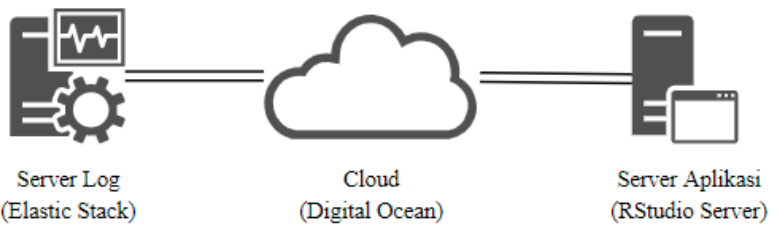

Gambar 2. Desain arsitektur

Server Log menggunakan Elastic Stack yang akan mengolah data metrik dari Server Aplikasi. Pada Server Aplikasi digunakan RStudio Server untuk mengolah data dengan bahasa pemrograman $r$.
TABEL I

SPESIFIKASI SERVER

\begin{tabular}{|l|l|l|}
\hline No & Komponen & Keterangan \\
\hline 1 & Processor & $2 \mathrm{CPU}$ \\
\hline 2 & RAM & $4 \mathrm{~GB}$ \\
\hline 3 & HDD & $80 \mathrm{~GB}$ \\
\hline 4 & Lokasi & Singapura \\
\hline 5 & Tarif & \$20 / Bulan \\
\hline
\end{tabular}

Kedua server menggunakan spesifikasi server yang sama dengan detail komponen seperti yang ditunjukkan Tabel I, untuk sistem operasi yang dipakai ialah Ubuntu 20.04. Akses server yang berada di cloud menggunakan tool tambahan yaitu Putty dengan akses ke IP Public server menggunakan protokol SSH dan login password yang telah di set saat pembuatan akun Digital Ocean.

\section{B. Implementasi}

Komponen Elastic Stack yang digunakan pada sisi server manajemen log dan metrik ialah Logstash, Elasticsearch dan Kibana. Logstash merupakan perangkat lunak sumber terbuka untuk mengumpulkan dan menguraikan log kemudian menyimpannya di Elasticsearch [13]. Logstash difungsikan untuk menerima input data dari Metricbeat yang berada pada server aplikasi untuk selanjutnya diteruskan menuju Elasticsearch dengan terlebih dahulu mendefinisikan penamaan index agar disimpan berdasarkan tanggal tiap harinya. Konfigurasi ini dibuat pada satu file khusus dengan nama logstash.conf yang disimpan dalam folder /etc/logstash/conf.d/. Port default yang digunakan Logstash ialah 5044. Hasil output Logstash akan disimpan dalam bentuk index oleh Elasticsearch. Elasticsearch adalah mesin pencari dan analisis teks open source yang sangat skalabel yang memungkinkan pengguna untuk menyimpan, mencari, dan menganalisis data dalam jumlah besar dengan cepat [14]. Kibana menjadi user interface dari Elasticsearch dimana manajemen index log berada didalamnya [15]. Konfigurasi Kibana berada pada directory letc/kibana/kibana.yml, koneksi dengan Elasticsearch dan port yang dipakai di atur dalam file ini. Visualisasi grafik dan dashboard yang dipakai untuk memantau data metrik server aplikasi dapat menggunakan sample yang disediakan oleh assets module. Akses Kibana pada browser dengan alamat http://IP_Public_Server_Log:5601.

Pada server aplikasi yang digunakan untuk menjalankan RStudio Server dipasang Beats, Beats adalah agen untuk pengirim data tujuan tunggal [16]. Salah satu jenis Beats ialah Metricbeat. Metricbeat akan meneruskan metrik sistem operasi dan juga statistik layanan yang berjalan di sistem ke Elasticsearch atau Logstash secara berkala [17]. Data metrik tersebut dapat berupa CPU, memori dan service yang berjalan didalamnya. Pastikan output.logstash pada file konfigurasi di /etc/metricbeat/metricbeat.yml menuju IP milik server Elastic Stack. 


\section{Pengujian}

Untuk dapat mengetahui penggunaan sumber daya server aplikasi dalam menangani RStudio dilakukan pengujian pada saat user menjalankan script $\mathrm{R}$ didalamnya. Diberikan skenario pemakaian aplikasi secara berjenjang oleh beberapa user untuk melihat batas maksimal resources server dan pengaruhnya terhadap kinerja. Aplikasi RStudio diakses via browser di alamat http://IP_Public_Server_Aplikasi:8787. Script R diambil dari website kaggle.com dengan durasi run time bervariasi. Script $\mathrm{R}$ didapat dengan ekstensi $\mathrm{R}$ Markdown (.Rmd) lalu dikonversi menjadi ekstensi $\mathrm{R}$ (.R) dengan menggunakan fungsi knitr::purl(). Untuk menjalankan aplikasi secara simultan menggunakan addins Cron scheduler pada RStudio dan ditentukan waktunya agar running bersamaan. Detail skenario pengujian pada Tabel II.

TABEL II

SKENARIO PENGGUNAAN RSTUDIO

\begin{tabular}{|l|l|l|}
\hline No & Jumlah User & Run Time Script \\
\hline 1 & 1 User & 2 Menit, 7 Menit \\
\hline 2 & 2 User & 2 Menit, 7 Menit \\
\hline 3 & 3 User & 2 Menit, 7 Menit \\
\hline 4 & 4 User & 2 Menit, 7 Menit \\
\hline 5 & 5 User & 2 Menit, 7 Menit \\
\hline
\end{tabular}

Secara bertingkat script $\mathrm{R}$ dijalankan mulai dari 1 user hingga 5 user atau lebih untuk melihat perubahan durasi waktu penyelesaiannya.

\section{Analisa}

Pada tahap ini dilakukan analisa dari data hasil pengujian aplikasi berupa besaran CPU Usage dan Memory Usage yang ditunjukkan tiap sesinya. Mengolahnya menggunakan RStudio untuk di plotting guna menemukan korelasi antara jumlah pengguna aplikasi dengan konsumsi sumber daya server serta lamanya waktu proses penyelesaian script tersebut.

\section{HASIL DAN PEMBAHASAN}

Berdasarkan tahap-tahap metode penelitian, diperoleh hasil yang diuraikan seperti berikut ini:

\section{A. Implementasi Server}

Server aplikasi, dengan nama RSTUDIO-SERVER, sedangkan server manajemen metrik yaitu ELASTICSTACK di menu Droplets DigitalOcean seperti yang ditampilkan pada Gambar 3.

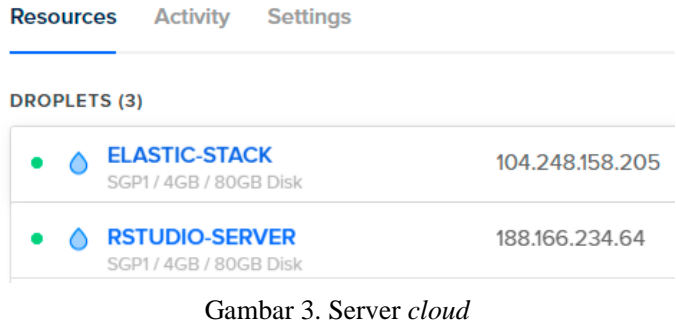

Masing-masing server mendapat 2 ip publik yang dapat di akses di internet untuk dapat saling terhubung satu sama lain. Proses kerja sistem mulai dari pengumpulan, penyimpanan dan visualisasi data metrik diurutkan sebagai berikut:

1) Beats: Saat Server Aplikasi yaitu RStudio Server mulai digunakan oleh pengguna untuk menjalankan script tiap sesinya, data metrik yang tercatat akan dikumpulkan oleh Metricbeat, seperti yang ditampilkan Gambar 4.

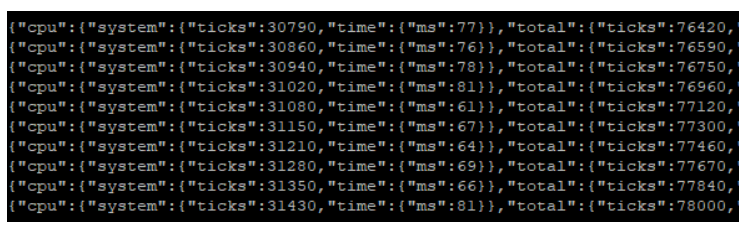

Gambar 4. Data metrik

Data metrik sistem berupa CPU Usage dan Memory Usage maupun indikator lain yang dihasilkan server akan diteruskan ke Logstash.

2) Logstash: Sesuai dengan file konfigurasi seperti Gambar 5, yaitu menerima input dan memproses outputnya menjadi bentuk index yang dicatat setiap harinya.

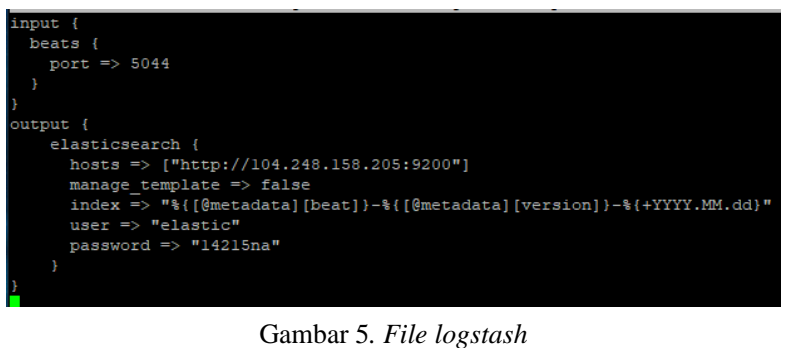

Input berupa metrik dari beats masuk melalui port 5044, untuk selanjutnya dihasilkan output berupa index yang akan disimpan oleh Elasticsearch pada Server Elastic Stack.

3) Elasticsearch: Berdasarkan script Logstash yang dibuat, data metrik dihimpun per hari, artinya akan dibuat file index dengan format nama mengikuti tanggal secara berkala yang ditunjukkan Gambar 6 .

\begin{tabular}{clc} 
Name & Health & Status \\
\hline metricbeat-7.9.3-2021.08.04 & $\bullet$ yellow & open \\
\hline metricbeat-7.9.3-2021.08.06 & $\bullet$ yellow & open \\
\hline metricbeat-7.9.3-2021.08.05 & $\bullet$ yellow & open \\
Gambar 6. Index &
\end{tabular}

File index yang telah dibuat setiap harinya akan menyimpan catatan data metrik dari server pada hari yang sama, nantinya periode waktu ditampilkan keseluruhan membentuk timeline pada Kibana.

4) Kibana: Kibana akan memvisualkan data metrik yang tersimpan didalam index menjadi bentuk grafik beraneka jenis, contohnya Gambar 7 . 


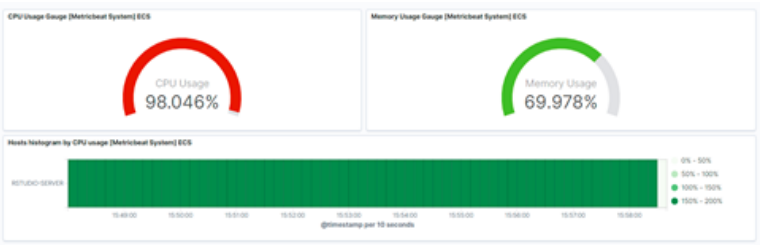

Gambar 7. Dashboard kibana

Pada Dashboard yang ada dapat dipantau tingkat konsumsi sumber daya server dari tiap sesi ujicoba menjalankan script R. Selain itu tersedia pula timeline untuk memudahkan dalam menganalisanya. Dashboard [Metricbeat System] Overview ECS berisi visualisasi grafik dari jumlah host yang di monitor, CPU Usage, Memory Usage, Disk Usage dan keluar masuk trafik.

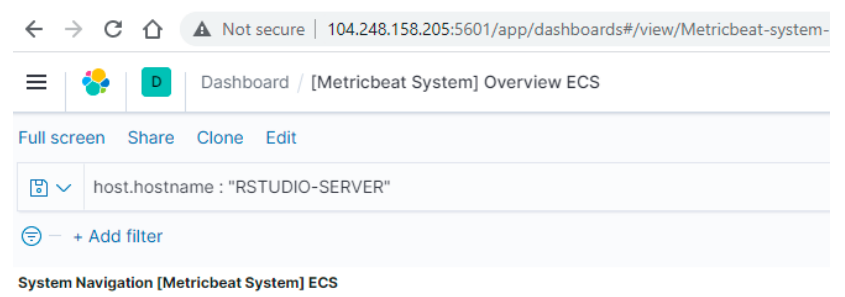

System Overview $\mid$ Host Overview $\mid$ Containers overview

Number of hosts [Metricheat

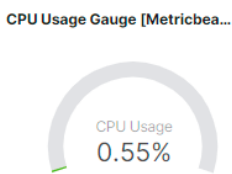

Memory Usage Gauge [Metri...

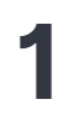

$0.55 \%$

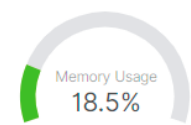

Top Hosts By CPU (Realtime) [Metricbeat System] ECS

RSTUDIO-SERVER

Gambar 8. Monitoring server aplikasi

Pada Gambar 8 menunjukkan data metrik dari server aplikasi (RSTUDIO-SERVER) telah masuk dan dapat dipantau melalui grafik pada server manajemen metrik (ELASTIC-STACK).

\section{B. Pengujian}

Pengujian pertama penggunaan RStudio dengan menjalankan script $\mathrm{R}$ dengan durasi run time selama 2 menit atau 120 second. Menggunakan dataset titanic.csv yang dibagi menjadi data training dan data test. Seperti yang ditunjukkan Gambar 9.

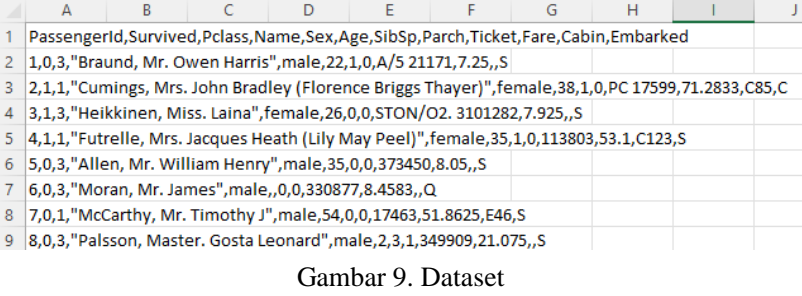

Dataset berisi data penumpang kapal Titanic dengan berbagai detil informasi seperti golongan kelas, nomor kabin, umur, status dan data pendukung lainnya yang dapat di analisa lebih jauh. Untuk coding program R dengan tema Predicting Titanic Survival using Five Algorithms seperti ditampilkan Gambar 10, ditulis oleh Thialaksha Silva dari situs kaggle dengan link sumber berikut: https://www.kaggle.com/thilakshasilva/predicting-titanicsurvival-using-five-algorithms.

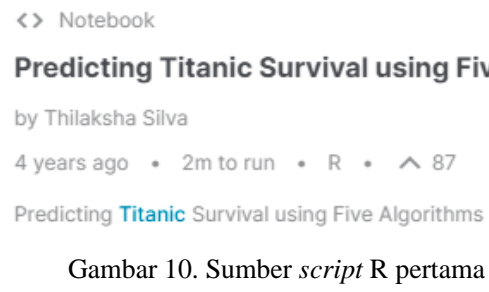

RStudio diakses oleh masing-masing user dan di set jadwal untuk running script tiap sesinya bergantian oleh 1 user, 2 user, hingga 5 user. Data metrik dari server aplikasi saat menjalankan script R akan terlihat pada server Elastic Stack seperti yang ditunjukkan Gambar 11.

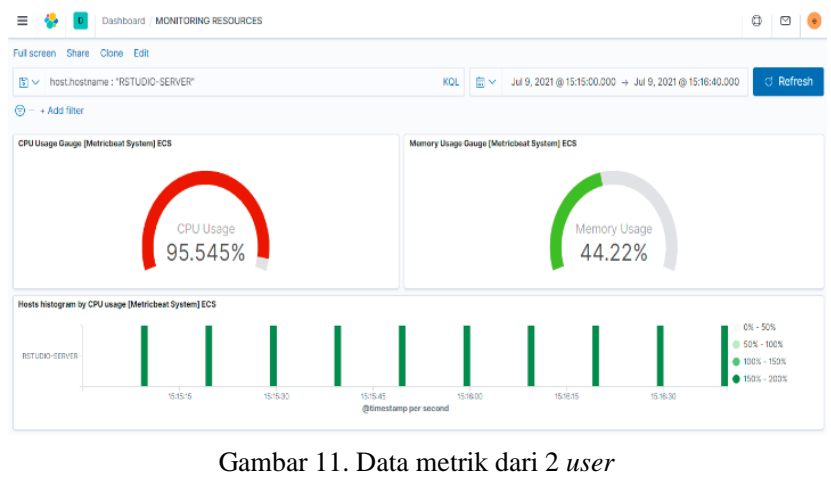

Data penggunaan resources server yang tercatat pada seluruh sesi ditampilkan Tabel III.

TABEL III DATA RESOURCES

\begin{tabular}{|l|l|l|l|l|}
\hline No & $\begin{array}{l}\text { Jumlah } \\
\text { User }\end{array}$ & $\begin{array}{l}\text { CPU } \\
\text { Usage }(\%)\end{array}$ & $\begin{array}{l}\text { Memory } \\
\text { Usage } \\
(\%)\end{array}$ & $\begin{array}{l}\text { Durasi } \\
\text { Selesai (sec) }\end{array}$ \\
\hline 1 & 1 User & 46,73 & 25,33 & 100 \\
\hline 2 & 2 User & 92,34 & 44,44 & 100 \\
\hline 3 & 3 User & 93,48 & 59,85 & 150 \\
\hline 4 & 4 User & 95,35 & 75,17 & 200 \\
\hline 5 & 5 User & 95,17 & 93,02 & 260 \\
\hline
\end{tabular}

Pengujian kedua masih menggunakan dataset yang sama namun dengan script $\mathrm{R}$ yang memiliki run time 7 menit / 420 second yang ditulis oleh Liam Morgan pada situs kaggle dengan judul Titanic - Top $8 \%$ with Random Forests $(R)$ seperti yang ditampilkan pada Gambar 12, sumber terkait dapat diakses melalui link : https://www.kaggle.com/lmorgan95/titanic-top-8-withrandom-forests-r. 
(〉) Notebook

Titanic - Top $8 \%$ with Random Forests (R)

by Liam Morgan

2 years ago $-7 m$ to run $\cdot R \cdot \wedge 16$

Titanic - Top $8 \%$ with Random Forests (R)

Gambar 12. Sumber script R kedua

Hasil pada pengujian kedua dicatat dan dirangkum seperti yang ditunjukkan pada Tabel IV:

TABEL IV

DATA RESOURCES

\begin{tabular}{|l|l|l|l|l|}
\hline No & $\begin{array}{l}\text { Jumlah } \\
\text { User }\end{array}$ & $\begin{array}{l}\text { CPU } \\
\text { Usage } \\
(\%)\end{array}$ & $\begin{array}{l}\text { Memory } \\
\text { Usage (\%) }\end{array}$ & $\begin{array}{l}\text { Durasi } \\
\text { Selesai (sec) }\end{array}$ \\
\hline 1 & 1 User & 50,10 & 32,64 & 380 \\
\hline 2 & 2 User & 99,29 & 53,96 & 380 \\
\hline 3 & 3 User & 98,05 & 69,98 & 640 \\
\hline 4 & 4 User & 98,61 & 82,21 & 790 \\
\hline 5 & 5 User & 98,23 & 95,56 & 990 \\
\hline
\end{tabular}

Dari pengujian kedua didapat pola yang sama dengan pengujian pertama, dimana durasi penyelesaian script menjadi lebih panjang secara signifikan pada penggunaan aplikasi lebih dari 2 user.

\section{Analisa}

Untuk memudahkan analisa data yang telah dihimpun dari skenario pengujian sebelumnya dan melihat pengaruh yang ditimbulkan maka perlu dibuat grafiknya. Data diolah dengan bahasa $\mathrm{R}$ pada RStudio menggunakan library ggplot2 yang menyediakan beragam kebutuhan visualisasi. Data Jumlah User ditempatkan sebagai sumbu $\mathrm{x}$, untuk sumbu y menampilkan data persentase dari CPU Usage dan Memory Usage, ditambahkan pula secondary axis untuk data Durasi Selesai. Pada grafik pengujian pertama di Gambar 13 menunjukkan server aplikasi mampu melayani 2 user bersamaan dengan durasi penyelesaian script yang dijalankan 100s atau pada tingkat optimal.

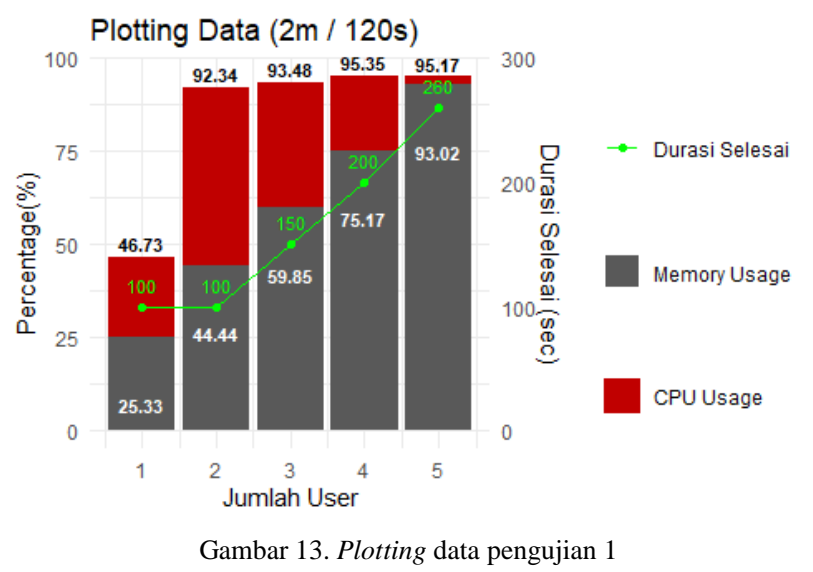

Gambar 13. Plotting data pengujian 1
Saat dipakai oleh 3 user dan 4 user, mulai terjadi peningkatan durasi selesai yaitu 150s dan 200s atau tingkat sedang. Untuk 5 user simultan waktu yg dibutuhkan untuk menyelesaikan yaitu 260s, masuk tingkat berat. Lebih dari 5 user terdapat 1 atau 2 task yang tidak diselesaikan (killed). Dibuat 3 tingkatan performa mulai dari optimal, sedang dan berat, keterangan lebih lengkap pada Tabel V.

TABEL V

TINGKATAN PERFORMA RUN TIME 120S

\begin{tabular}{|l|l|l|l|}
\hline No & Tingkat & Keterangan & Max. User \\
\hline 1 & Optimal & Durasi selesai dibawah run time & 2 \\
\hline 2 & Sedang & $\begin{array}{l}\text { Durasi selesai tidak lebih 2x run } \\
\text { time }\end{array}$ & 4 \\
\hline 3 & Berat & Durasi selesai lebih 2x run time & $>=5$ \\
\hline
\end{tabular}

Berdasarkan hasil durasi waktu yang diperlukan sistem menyelesaikan script di pengujian pertama, dapat dikelompokkan menjadi 3 tingkatan performa dimana hasil optimal penggunaan aplikasi yaitu penyelesaian dibawah run time didapat saat maksimal 2 user secara simultan menjalankan script.

Pada grafik pengujian kedua di Gambar 14 menunjukkan server aplikasi mampu melayani 2 user bersamaan dengan durasi penyelesaian script yang dijalankan 100s atau berada pada tingkat optimal.

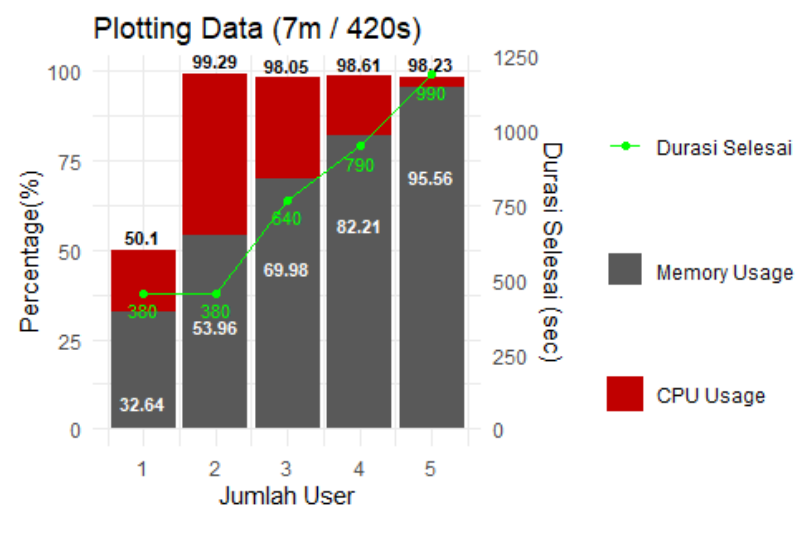

Gambar 14. Plotting data pengujian 2

Saat pengguna bertambah menjadi 3 user dan 4 user, mulai terjadi peningkatan durasi selesai yaitu $150 \mathrm{~s}$ dan 200 s atau tingkat sedang. Durasi waktu penyelesaian script meningkat signifikan menjadi 990s saat digunakan oleh 5 user sekaligus, dalam tingkatan performa dikategorikan berat. Hasil lengkap pada Tabel VI.

TABEL VI

TINGKATAN PERFORMA RUN TIME 420S

\begin{tabular}{|l|l|l|l|}
\hline No & Tingkat & Keterangan & Max. User \\
\hline 1 & Optimal & Durasi selesai dibawah run time & 2 \\
\hline 2 & Sedang & $\begin{array}{l}\text { Durasi selesai tidak lebih 2x run } \\
\text { time }\end{array}$ & 4 \\
\hline 3 & Berat & Durasi selesai lebih 2x run time & $>=5$ \\
\hline
\end{tabular}


Pengelompokkan tingkat performa pada hasil pengujian kedua sama dengan pengujian pertama, yaitu maksimal 2 user untuk hasil optimal penggunaan aplikasi.

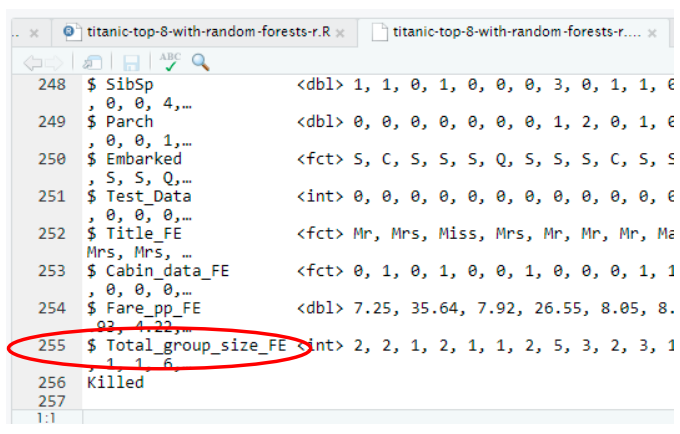

Gambar 15. Task tidak diselesaikan

Di percobaan dengan 6 user, terdapat proses dari script yang dijalankan user tidak dapat diselesaikan. Artinya, Server Aplikasi tidak mampu melayani penggunaan aplikasi lebih dari 5 user.

\section{KESIMPULAN}

Berdasarkan hasil yang ditunjukkan dari plotting data server aplikasi diperoleh korelasi antara besarnya pemakaian resources server oleh penggunaan aplikasi secara multiuser terhadap waktu yang diperlukan aplikasi untuk menyelesaikan script $\mathrm{R}$ yang dijalankan. Sehingga didapat kesimpulan bahwa server dengan spesifikasi $2 \mathrm{CPU}$ dan RAM 4GB mampu melayani secara simultan maksimal 2 user untuk menjalankan script $\mathrm{R}$ yang memiliki run time 2 menit / 120s dan 7 menit / 420s dengan performa yang optimal, untuk performa sedang maksimal 4 user, dan tingkat performa berat dimana waktu penyelesaian memakan waktu 2 kali lebih lama dari run time terjadi saat user yang menjalankan script maksimal 5 user, lebih dari 5 user beberapa proses di antara user berstatus killed / tidak selesai.

\section{UCAPAN TERIMA KASIH}

Terimakasih kepada Fakultas Teknologi Industri Universitas Trisakti atas bantuan dan dukungan yang diberikan terhadap penelitian ini hingga selesai.

\section{REFERENSI}

A. Syaichul Hadi and M. Alfan Rosid, "Aplikasi Edukasi Pemecahan Masalah pada Vulnerability Server Berbasis Web," J. Tek. Inform. dan Sist. Inf., vol. 7, no. 1, pp. 218-230, 2021, doi: 10.28932/jutisi.v7i1.3405.

[2] Husain, M. Zarlis, Z. Nasution, H. T. Sihotang, and S. Wahyuni, "Filsafat Ilmu Komputer Dan Cloud Computing Secara Etimologis," J. Mantik Penusa, vol. 2, no. 2, pp. 15-21, 2018.
[3] I. Musabirov, P. Okopny, and S. Pozdniakov, "Enabling information access in virt ual learning environment. The case of data science minor," ACM Int. Conf. Proceeding Ser., vol. 2327-Octo, 2016, doi: 10.1145/2971485.2996754.

[4] F. W. Christanto and M. S. Suprayogi, "Pemantauan Sumber Daya Virtual Server Pada Cloud Computing Universitas Semarang Menggunakan Network Monitoring System," Simetris J. Tek. Mesin, Elektro dan Ilmu Komput., vol. 8, no. 2, p. 629,2017 , doi: $10.24176 /$ simet.v8i2.1555.

[5] F. M. G et al., "Analisis Performansi Metrik CPU Dan Memory Pada Windows Azure Virtual Machine (VM ) dan Amazon Web Service Elastic Compute Cloud ( EC2 ),” vol. 7, no. 2, pp 6975-6983, 2020

[6] J. Ellingwood and V. Kalsin, "How To Install Elasticsearch, Logstash, and Kibana (Elastic Stack) on Ubuntu 18.04," 2018. https://www.digitalocean.com/community/tutorials/how-toinstall-elasticsearch-logstash-and-kibana-elastic-stack-onubuntu-18-04.

[7] K. Lotz, "Integrating the Elastic Stack into ExplorViz to Collect Logs and Runtime Metrics," 2019.

[8] W. Sholihah, S. Pripambudi, and A. Mardiyono, "Log Event Management Server Menggunakan Elastic Search Logstash Kibana (ELK Stack)," JTIM J. Teknol. Inf. dan Multimed., vol. 2, no. 1, pp. 12-20, 2020, doi: 10.35746/jtim.v2i1.79.

[9] M. Bajer, "Building an IoT data hub with elasticsearch, Logstash and Kibana," Proc. - 2017 5th Int. Conf. Futur. Internet Things Cloud Work. W-FiCloud 2017, vol. 2017-Janua, no. August 2017, pp. 63-68, 2017, doi: 10.1109/FiCloudW.2017.101.

[10] C. Tarigan and D. Angela, "Sistem Pengawasan Kinerja Jaringan Server Web Apache dengan Log Management System ELK ( Elasticsearch, Logstash, Kibana )," J. Telemat. Ed. Ind. Eng. Semin. Call Pap., vol. 1, no. 1, pp. 7-14, 2018.

[11] F. Abd. Hadi, M. Ahyar, and I. Syamsuddin, "ELK : Teknologi Mesin Pencari Big Data Terdistribusi," Semin. Nas. Tek. Elektro dan Inform. 2018, no. September, pp. 333-338, 2018.

[12] R. University, "Graphic Examples." https://www.ruf.rice.edu/ bioslabs/tools/data_analysis/graphic _examples.html.

[13] A. F. Rochim, M. A. Aziz, and A. Fauzi, "Design Log Management System of Computer Network Devices Infrastructures Based on ELK Stack," ICECOS 2019 - 3rd Int. Conf. Electr. Eng. Comput. Sci. Proceeding, no. May 2020, pp. 338-342, 2019, doi: 10.1109/ICECOS47637.2019.8984494.

[14] R. Rosdiana, T. Eddy, S. Zawiyah, and N. Y. U. Muhammad, "Analisis Sentimen pada Twitter terhadap Pelayanan Pemerintah Kota Makassar," Proceeding SNTEI, pp. 87-93, 2019.

[15] B. A. Sujatmoko and A. Sujarwo, "Desain Pengamanan Ganda pada Kontrol Akses Ruang dengan RFID pada Institusi Pendidikan Tinggi," Semant. Sch., pp. 27-36, 2019, [Online]. Available: https://www.semanticscholar.org/paper/DesainPengamanan-Ganda-pada-Kontrol-Akses-Ruang-SujatmokoSujarwo/b2e6ad905fcc2ce8e3d67a81d370bffb4313dd7b.

[16] K. Yamnual, P. Phunchongharn, and T. Achalakul, "Failure detection through monitoring of the scientific distributed system," Proc. 2017 IEEE Int. Conf. Appl. Syst. Innov. Appl. Syst. Innov. Mod. Technol. ICASI 2017, pp. 568-571, 2017, doi: 10.1109/ICASI.2017.7988485.

[17] M. Harikanth and P. Rajarajeswari, "Malicious event detection using ELK stack through cyber threat intelligence," Int. J. Innov. Technol. Explor. Eng., vol. 8, no. 7, pp. 882-886, 2019. 